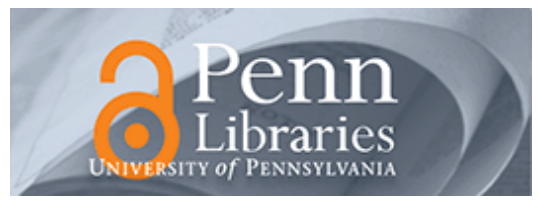

University of Pennsylvania

ScholarlyCommons

Marketing Papers

Wharton Faculty Research

1994

\title{
Would Mandatory Attendance be Effective for Economics \\ Classes?
}

\section{J. Scott Armstrong}

University of Pennsylvania, armstrong@wharton.upenn.edu

Follow this and additional works at: https://repository.upenn.edu/marketing_papers

Part of the Behavioral Economics Commons, Cognition and Perception Commons, Cognitive Psychology Commons, Curriculum and Instruction Commons, Educational Methods Commons, Educational Psychology Commons, Higher Education Commons, Higher Education Administration Commons, and the Marketing Commons

\section{Recommended Citation}

Armstrong, J. S. (1994). Would Mandatory Attendance be Effective for Economics Classes?. http://dx.doi.org/10.2139/ssrn.634127

This is an unpublished manuscript.

This paper is posted at ScholarlyCommons. https://repository.upenn.edu/marketing_papers/252

For more information, please contact repository@pobox.upenn.edu. 


\title{
Would Mandatory Attendance be Effective for Economics Classes?
}

\author{
Abstract \\ Romer (1993) suggests that universities should undertake experiments that would test the value of \\ mandatory attendance for economics courses. He presents evidence showing that those who attended \\ his classes received higher grades on his exams and concluded that "an important part of the relationship \\ [to the course grade] reflects a genuine effect of attendance." This conclusion is likely to be welcomed by \\ some economics professors. \\ In this note, I address two issues. First, what does prior research imply about a relationship between \\ attendance and learning? Second, does Romer's own evidence support his conclusion that mandatory \\ attendance is beneficial? \\ Disciplines \\ Behavioral Economics | Business | Cognition and Perception | Cognitive Psychology | Curriculum and \\ Instruction | Educational Methods | Educational Psychology | Higher Education | Higher Education \\ Administration | Marketing

\section{Comments} \\ This is an unpublished manuscript.
}


Published on the Internet only.

\title{
Would Mandatory Attendance Be Effective for Economics Classes?
}

\author{
J. Scott Armstrong \\ The Wharton School, University of Pennsylvania
}

Romer (1993) suggests that universities should undertake experiments that would test the value of mandatory attendance for economics courses. He presents evidence showing that those who attended his classes received higher grades on his exams and concluded that "an important part of the relationship [to the course grade] reflects a genuine effect of attendance." This conclusion is likely to be welcomed by some economics professors.

In this note, I address two issues. First, what does prior research imply about a relationship between attendance and learning? Second, does Romer's own evidence support his conclusion that mandatory attendance is beneficial?

\section{Prior Evidence on the Effects of Attendance}

Romer cites only two prior studies. One, Park and Kerr (1990), used a similar design and reached similar conclusions about the values of attendance. The other, Schmidt (1983) was similar in that it regressed student grades against various factors. It also found attendance to be related to grades. The results were, however, a bit difficult to interpret. Judging from Schmidt's study, students can earn lower grades by studying more for the final exam.

But if one looks beyond research that is specifically addressed at mandatory attendance, there is much additional research that is relevant. Most is published in the areas of education and psychology. Rather than attempt to provide a comprehensive review of this evidence, I provide some basic conclusions along with some key studies. For a general review of this literature, see Kohn (1993).

One conclusion from the literature is that people learn most effectively when they feel that they have personal responsibility for their learning. By this, we mean that they perceive themselves as the primary force for learning. Formal education often involves procedures for removing this feeling of responsibility. It substitutes bureaucratic requirements, and the students must demonstrate that they have met these requirements. (This is sometimes referred to as "being held responsible," a passive approach, which is quite different from my use of the term "responsible." For a further discussion of the meaning of "responsibility" in learning, see Bacon, 1993). Thus, required courses with mandatory attendance are expected to reduce one's feeling of responsibility for learning. At least two psychological principles are related to the acceptance of responsibility. One is "social facilitation" and the other is "attribution theory."

Zajonc (1965) reviewed evidence on social facilitation. This research, done on rats and on students, led to the conclusion that when subjects can observe the critical responses of others, their learning is inhibited. This led Zajonc to conclude that (if one believed the studies), "students should study alone." (He did not provide advice for the rats.)

The loss of responsibility is also related to attribution theory. When an activity is associated with a reward, people conclude that the reason that they are performing the activity is to achieve the reward and they lose interest in the activity itself. Thus, with mandatory attendance at economics classes, people might conclude that the reason that they attend the class is to get credit for attending, rather than because of an interest in learning economics.

Condry (1977) reviewed the evidence on attribution theory and concluded that extrinsic rewards decrease intrinsic motivation for learning. Barrett and Boggiano (1988) provided an updated review of this literature with similar conclusions. However, despite this, they also found that parents and college-age adults prefer that teachers 
use extrinsic rewards. Boggiano et al. (1992) show how the extrinsic control over students leads to a feeling of helplessness and they conclude that schools may teach students nothing other than "how to obey."

The above should not be that surprising to economists. If the nature of a transaction is changed from providing a learning opportunity to providing a set of requirements, then students are likely to believe that they have completed the transaction when they have fulfilled the requirements.

Given these findings, one would expect that important learning is unlikely to take place in formal classes. Interestingly, Tough (1982) studied important self-reported learning episodes by adults and concluded that, while people were able to report many important things that they learned, few learning episodes occurred in groups, especially if the group had a teacher.

In a study about learning economics, Attiyeh and Lumsden (1972) reported on a large scale study $(30,000$ students) of economics courses in U.K. high schools and universities. Attendance was substantially higher on average than that found by Romer ( $86 \%$ versus $67 \%$ ). (This suggests that attendance may be declining or that there are cultural differences.) The criteria were based on before and after studies of knowledge in economics. Attendance at lectures was not related to learning, although attendance at discussion sections was.

The interesting thing about this prior research is that the results conflict with what we have all learned from our personal experience as students and teachers. I know, for example, that those who attend my classes learn more than those who do not! But, as the saying goes, "if we believe that we can only learn from experience, how can we learn that we can't?"

\section{Romer's Evidence}

Romer found that there is much absenteeism in economics classes at prestigious universities. It averaged about $1 / 3$. This is good news for someone studying how absenteeism relates to grades.

Romer does a good job of statistically controlling for other variables such as intelligence and effort. This use of controls for student motivation reduced the relationship of attendance and grades. But it seems doubtful that Romer's control variables were sufficient to account for all other important sources of variation.

One problem is that Romer does not measure the change in knowledge that takes place as a result of the course. Instead, he measures students' knowledge level at the end of the course. It seems reasonable to expect that those with interests and abilities in economics would know more when the course starts and they would also be more likely to attend classes. That is, attendance should be related to knowledge even if no learning occurred in the classes. Furthermore, there is the problem that grades in exams have little relationship to peoples' ability to use this knowledge effectively (Hoyt 1966).

Romer concludes that students would learn more if attendance were mandatory. Based on the evidence from the previous studies, I expect that they will earn less, holding time constant. That is, a given hour that a student spends studying on her own should result in more learning than an hour spent in a mandatory class. And a student who attends voluntarily should learn more than if she were required to attend.

One argument is that people need to spend some time to learn and that mandatory attendance would increase the time spent. Here again, I would predict the opposite. According to attribution theory, students are likely to assume that the reason that they are attending the class is that they are required to do so. Once they fulfill this duty, what is the need to learn economics outside of the classroom?

\section{Conclusions}

Romer restricted his search to studies of mandatory attendance in economics courses. Given a wider perspective, much relevant research exists. When Romer's finding are viewed in this larger context, I expect that 
mandatory attendance at economics classes would harm learning. Nevertheless, cost aside, it is difficult to argue against doing good experiments about how people learn most effectively.

\section{References}

Attiyeh, Richard and K. G. Lumsden (1972), "Some modern myths in teaching economics: The U.K. experience," American Economic Review, 62, 429-433.

Bacon, Charles S. (1993), “Student responsibility for learning,” Adolescence, 28, 199-212.

Barrett, Marty and Ann K. Boggiano (1988), "Fostering extrinsic orientations: Use of Reward strategies to motivate children," Journal of Social and Clinical Psychology, 6, 293-309.

Boggiano, Ann K. et al. (1992), "Helplessness deficits in students: The role of motivational orientation," Motivation and Emotion, 16, 271-296.

Condry, John (1977), "Enemies of exploration: Self-initiated versus other-initiated learning," Journal of Personality and Social Psychology, 35, 459-477.

Hoyt, D. T. (1966), “College grades and adult achievement: A review of the literature,” The Educational Record, 47, 70-75.

Kohn, Alfie (1993), Punished by Rewards. New York: Houghton Mifflin.

Romer, David (1993), “Do students go to class? Should they?” Journal of Economic Perspectives, 7, 167-174.

Tough, Allen (1982), Intentional Changes. Chicago: Follet.

Zajonc, Robert B. (1965), “Social facilitation,” Science, 149 (July 16), 269-274. 